\title{
POSTANI SVKRI ZNALAC - RADIONICE INFORMACIJSKOG OPISMENJAVANJA STUDENATA
}

\author{
Sandra Cuculić \\ Sveučilište u Rijeci, Sveučilišna knjižnica Rijeka - Podružnica Kampus, Rijeka, Hrvatska \\ University of Rijeka, University Library Rijeka - University Campus division, Rijeka, Croatia \\ scuculic@svkri.hr
}

Jana Krišković Baždarić*

jkriskovic@svkri.hr

Branka Pemper*

bpemper@svkri.hr

* Sveučilište u Rijeci, Sveučilišna knjižnica Rijeka, Rijeka, Hrvatska

University of Rijeka, University Library Rijeka, Rijeka, Croatia

\begin{abstract}
Sažetak
Pristup neograničenim elektroničkim sadržajima utjecao je na potpuni zaokret u poslovanju sveučilišnih i visokoškolskih knjižnica danas. Uz istovremeno opadanje broja posudbi fizičkih jedinica građe i porast fizičkih posjeta knjižnici i korištenja virtualnih usluga, knjižnica je kao jednu od svojih prvih obveza prepoznala edukaciju svojih studenata u stjecanju vještina i snalaženju u brojnim programima i alatima vezanima za pretraživanje, korištenje, organiziranje i vrednovanje informacija. Sveučilišna knjižnica Rijeka 2016. godine pokrenula je edukacijski program pod nazivom Postani SVKRI znalac sa ciljem pružanja podrške studentima u studiranju i njihovom znanstveno-istraživačkom radu. Program se dijeli na radionice upoznavanja s knjižnicom i uputama za njezino korištenje i one u kojima studenti stječu znanja i vještine pretraživanja i vrednovanja informacija. Nagli porast korištenja informacija i literature u digitalnoj sferi donio je sa sobom i potrebu dodatne edukacije usko vezane uz pristup informaciji, autorsko pravo i povećanu pojavu plagiranja. Sveučilišna knjižnica Rijeka je programom Postani SVKRI znalac omogućila studentima da steknu dodatna znanja i vještine u informacijskom polju, a važnost samog programa prepoznali su i nastavnici pojedinih kolegija Sveučilišta u sklopu kojih se pojedine radionice i izvode u određenim terminima.
\end{abstract}

Ključne riječi: Postani SVKRI znalac, Sveučilišna knjižnica Rijeka, visokoškolska knjižnica, informacijska pismenost

\section{Uvod}

Napredak digitalne tehnologije i dostupnost informacijskih izvora na internetu omogućili su studentima lako dostupan pristup neograničenom broju elektroničkih sadržaja potrebnih za učenje i studiranje. Posjete Sveučilišnoj knjižnici Rijeka (Dalje u tekstu: Knjižnica) u potrazi za tiskanim udžbenicima i studentskom literaturom značajno opadaju, što je vidljivo u završnim godišnjim statistikama Knjižnice (Sveučilišna knjižnica Rijeka 2018). Iz godine u godinu zabilježen je pad broja posudbe tiskane građe, za razliku od porasta fizičkih posjeta koji uključuju boravak u ugodnom knjižničnom prostoru koji studentima služi za učenje i korištenje virtualnih knjižničnih usluga. Uzroke pada broja fizičke posudbe možemo potražiti $u$ promjenama i trendovima učenja studenata kojima su u sklopu studija i e-kolegija osigurani obrazovni elektronički materijali, kojima pristupaju jednostavno i besplatno s različitih vrsta tehnoloških uređaja, uz mogućnost preuzimanja sadržaja u svakom trenutku. 
Knjižničari informatori zaposleni u Odjelu rada s korisnicima Sveučilišne knjižnice Rijeka godišnje prate i evidentiraju potrebe studenata Sveučilišta i Veleučilišta u Rijeci. Tijekom 2016./2017. akademske godine proveli smo anketno istraživanje (Cuculić et al. 2017) među studentima korisnicima Knjižnice s ciljem istraživanja potencijalnih problema na koje nailaze $u$ digitalnom okruženju, a odnose se na korištenje, preuzimanje, pohranu i upotrebu digitalnih informacija. Rezultati koje smo dobili poslužili su kao jedna od smjernica u izradi modula Postani SVKRI znalac s obzirom na to da su ukazali na konkretne poteškoće studenata koje se odnose na nedovoljno poznavanje i korištenje alata za pohranu i organizaciju radova te uređenje referenci i izradu bibliografije, kao i problem nedovoljnog poznavanja autorskog prava i obveze citiranja literature bez obzira na digitalni i tiskani oblik ili izvor s kojega preuzimaju sadržaj. Ustanovili smo da je plagiranje studenata nenamjerna posljedica nepoznavanja autorskog prava i mogućnosti korištenja online i digitalnih sadržaja te neznanja o važnosti citiranja i navođenja literature.

Pristup znanstvenim informacijama putem računalne i digitalne tehnologije olakšao je učenje i studiranje, ali je pridonio pojavi različitih oblika povreda autorskih prava. Sukladno razvoju računalnih i digitalnih tehnologija mijenja se uloga sveučilišnih i visokoškolskih knjižnica koje bi svoju djelatnost trebale prilagoditi potrebama studenata. Sveučilišna knjižnica svoje je informacijske usluge usmjerila na razvoj online usluga kojima je olakšan pristup informacijama te izradu i održavanje radionica informacijskog opismenjavanja kojima studente educira kako pronaći, vrednovati, organizirati, koristiti i prenositi informacije u skladu s etičkim načelima informacijske pismenosti, čime pridonose sprečavanju plagiranja i ostalih oblika zloporabe informacija i povrede autorskih prava (IFLA 2012).

\section{Postani SVKRI znalac}

U svjetlu anketnog istraživanja provedenog među studentima, ali i sve veće potrebe uključivanja Sveučilišne knjižnice u obrazovni proces u obliku potpore studentima u sadržajima koji se vežu uz kvalitetnu pripremu pisanja radova, ali i znanstvenog istraživanja, 2016. godine pokrenuli smo edukacijski program Postani SVKRI znalac. Program se sastoji od pet modula/radionica u trajanju od 60 minuta. Radionice su namijenjene različitim studentskim potrebama, pa se tako prve dvije radionice (Upoznaj knjižnicu i Koristi knjižnicu) odnose na upoznavanje studenata s činjenicama o Sveučilišnoj knjižnici i praktične upute kako koristiti njezine usluge, prostor i građu. Preostale tri radionice (Pronađi u knjižnici, Organiziraj prikupljenu literaturu i Vrednuj radove) zajedno čine zaokruženi proces pretraživanja informacija, njihovog organiziranja te u konačnici korištenja i vrednovanja pri pisanju rada. U svjetlu promjena okruženja u kojem knjižnice egzistiraju, sve većeg razvoja i uporabe digitalne tehnologije, uloga knjižnice višestruko se promijenila. Neprestanim razvojem digitalnih izvora informacija i brojnih alatima za njihovo upravljanje i vrednovanje, edukacija u stjecanju vještina u njihovom korištenju danas je jedna od prvih obveza visokoškolske knjižnice. Edukacijskim programom $P o-$ stani SVKRI znalac Sveučilišna knjižnica zauzela je svoju poziciju u educiranju studenata i prenošenju informacijskih vještina potrebnih u današnjem visokoškolskom obrazovanju. Radionice su osmišljene i održavaju se u sklopu Odjela rada s korisnicima i nastale su kao odgovor na sve upite i zahtjeve koje smo na dnevnoj bazi dobivali od naših studenata. Upiti su se odnosili na pretraživanje baza podataka, izvore $\mathrm{u}$ otvorenom pristupu, nemogućnost pristupa znanstvenim radovima, upoznavanje s programima za upravljanje bibliografskim podacima, odabir časopisa za izdavanje vlastitog rada, pitanja vezana uz vidljivost radova itd. Radionice su za članove Sveučilišne knjižnice besplatne i održavaju se u knjižnici, u znanstveno-istraživačkoj čitaonici, ali sve češće i u sklopu kolegija određenih studijskih programa pisanja i metodologije znanstvenog rada.

\section{Modul 1: Upoznaj Sveučilišnu knjižnicu Rijeka}

Modul Upoznaj Sveučilišnu knjižnicu Rijeka odnosi se na upoznavanje Knjižnice i najčešće je namijenjen vanjskim korisnicima, odnosno onima koji ne trebaju usluge nego ih zanimaju znamenitosti (posebnosti) ustanove. Ovim su modulom obuhvaćene informacije o povijesnom razvoju knjižnice, njezinim zadaćama, baštinskim zbirkama, strukturi, programima i događanjima kroz godinu koji se odnose na obrazovanje korisnika, ali i programe stručne znanstvene i obrazovne djelatnosti u okviru funkcije matičnosti koju Knjižnica obnaša za Primorsko-goransku županiju. Polaznike se upoznaje s virtualnom zbirkom knjižnice koja obuhvaća repozitorije, digitaliziranu građu te licencirane elektroničke izvore. Predavanje obuhvaća organizirani obilazak Knjižnice uz stručno vodstvo diplomiranih knjižničara iz različitih odjeljenja. Modul Upoznaj knjižnicu u smislu vanjskih korisnika često koriste i skupine maturanata $i$ studenti prvih godina studija koji još nisu članovi Knjižnice, a koji se na ovaj način upoznaju s načinima poslovanja Sveučilišne knjižnice čije će im usluge tek trebati. 


\section{Modul 2: Koristi usluge Knjižnice}

Modul Koristi usluge Knjižnice namijenjen je specifičnim korisničkim skupinama, odnosno onima koji se namjeravaju služiti uslugama Knjižnice, a najčešće su to studenti i maturanti. Predavanje sadrži praktično upoznavanje s mogućnostima i pravilima korištenja Knjižnice, uz upoznavanje s prostorijama koje su na raspolaganju korisnicima. Polaznici se upoznaju s pravilima posudbe građe, pravilima korištenja građe u čitaonicama i opreme u čitaonicama kao i s ostalim uslugama u prostorijama Knjižnice. Modul objedinjuje tradicionalna i suvremena strujanja: naspram izvora u tiskanom obliku koji su krajnjem korisniku važni jer pojedine izvore može dobiti samo u tom obliku, korisnike se informira i o drugim načinima korištenja usluga putem e-zahtjeva te ih se upućuje na pretraživanja elektroničkih izvora u slobodnom pristupu, kao i onih u sklopu nacionalne nabave (pretplaćeni e-izvori pojedinih izdavača). Ovaj modul je jedan od najtraženijih i najčešće izvođenih jer obuhvaća osnovna znanja koja su korisniku potrebna da bi na potpun način koristio usluge Knjižnice.

\section{Modul 3: Pronađi u knjižnici}

Modul Pronađi u knjižnici namijenjen je specifičnim korisničkim skupinama, odnosno onima koji su već članovi Knjižnice i poznaju pravila i mogućnosti korištenja njezinih usluga. Radionica upoznaje polaznike s uputama za pronalaženje građe dostupne u Knjižnici i putem Knjižnice. Radionica obuhvaća informacije o alatima za pretraživanje dostupnim pri Sveučilištu u Rijeci te načinima korištenja tih alata. Zbog jednostavnosti korištenja te učinkovitosti pronalaženja potrebnih informacija, najviše je interesa pobudio Discovery servis. Discovery servis nudi najlakše početno pretraživanje unosom riječi u tražilicu po uzoru na Google, a popularan je ponajviše zbog sveobuhvatnosti rezultata prilikom tematskih pretraživanja. To je alat koji pretražuje fondove svih knjižnica sastavnica Sveučilišta u Rijeci, licencirane izvore dostupne na Sveučilištu, portal znanstvenih časopisa Republike Hrvatske HRČAK te druge odabrane znanstvene izvore u slobodnom pristupu. Discovery Servis integriran je u mrežnu stranicu Knjižnice, a mogu ga koristiti svi pripadnici riječke sveučilišne zajednice. Za one koji nisu članovi akademske zajednice, ali su članovi Sveučilišne knjižnice, pristup je omogućen s računala $u$ Knjižnici. Unatoč tome što Discovery Servis nudi širok spektar rezultata, pronađeni rezultati ne moraju uvijek odgovoriti na potrebe korisnika, stoga se na radionici polaznici informiraju i o mrežnim izvorima koji su dostupni nacionalnom licencom. Odabir elektroničkih zbirki pojedinih izdavača ovisi o interesu grupe pa se prema odabiru izdavača baze podataka daju upute za korištenje.
Radionica obuhvaća i pretraživanja specijalnih zbirki koje su dio fonda Knjižnice (Biblioteka Civica, povijesna zbirka, Repozitorije Sveučilišta u Rijeci). Navedene su zbirke izdvojene u posebnim katalozima stoga je potrebno posebno informirati polaznike o funkcionalnostima tih sučelja. Posebna pažnja pridaje se oblikovanju upita te odabiru ključnih riječi jer upravo o tome ovisi krajnji ishod pretraživanja. Ovaj je modul jako popularan među profesorima koji svoje studente žele uputiti na samostalno pretraživanje literature te istraživačima koji pretražuju specifično područje znanosti te im je za pronalazak adekvatnih informacija i izvora potrebno stručno vodstvo.

\section{Modul 4: Organiziraj prikupljenu literaturu}

Modul se prvenstveno odnosi na upućivanje polaznika u etički kontekst ispravnog navođenja literature kod izrade radova te upoznavanje s programom Mendeley za upravljanje bibliografskim podacima. Kroz upoznavanje s funkcionalnostima programa Mendeley (stvaranje vlastite knjižnice i organiziranje dokumenata, dodavanje citata i izrada bibliografskih popisa, mogućnost suradnje s kolegama na dijeljenju bibliografskih zapisa) studenti se upoznaju s pojmovima plagiranja i samoplagiranja, važnosti i mogućnostima ispravnog citiranja literature te važnosti pohrane i vođenja bilješki tijekom pisanja rada. Rad s programom Mendeley odnosi se na instalaciju programa i izradu korisničkog računa, upoznavanje sa sučeljem programa, strukturiranje vlastite knjižnice i organizaciju dokumenata, pretraživanje bibliografskih podataka, korištenje Mendeleyeva PDF preglednika za uređivanje dokumenata, kreiranje grupa unutar programa Mendeley za potrebe dijeljenja bibliografskih zapisa i suradnje s kolegama, korištenje Mendeleyeva alata Citation Plug In, te dodavanje citata iz materijala osobne knjižnice i izradu bibliografskih popisa. Cilj radionice je osposobiti studente za samostalnu izradu citata i popisa literature korištene $u$ znanstvenom istraživanju i na taj način povećati svjesnost i spriječiti plagiranje koje u većini slučajeva nastaje zbog zagubljenih bilješki o literaturi koja se koristi tijekom pisanja radova.

\section{Modul 5. Vrednuj radove}

Modul je namijenjen prvenstveno studentima doktorskog studija, a odnosi se na procese vrednovanja stručnog i znanstvenog rada. Polaznike učimo razlikama između recenzije kao kvalitativnog oblika i bibliometrijskih istraživanja kao kvantitativnog oblika vrednovanja. Ovaj modul pobuđuje veliki interes kod studenata doktorskih studija s obzirom na to da su oni na početku svoje istraživačke karijere, a radionica im pomaže da saznaju kako na 
temelju bibliometrijskih analiza u citatnim bazama podataka izračunati odjek znanstvenika u zajednici i na Sveučilištu. Kvantitativnim metodama mjeri se odjek njihova rada, ukupna produktivnost i citiranost koja može znatno utjecati na tijek njihove karijere. Trajanje radionice je jedan sat tijekom kojeg polaznike upoznajemo s osnovnim pojmovima iz bibliometrije i izradom bibliometrijskih analiza na temelju različitih pokazatelja, s naglaskom na kvantitativne pokazatelje koje treba sagledati s različitih aspekata i koristiti na ispravan način. Polaznike učimo koristiti i pretraživati citatne baze podataka Web Of Science Core Collection i Scopus, dok tijekom praktičnog dijela izrađuju bibliometrijske analize na temelju pretraživanja po prezimenu i imenu autora u bazi, kako bi dobili uvid u vlastitu indeksiranost, citiranost i samocitiranost radova, h-indeks, ali i uvid u poteškoće i pogreške u bazama na koje mogu naići prilikom pretraživanja. Polaznike učimo altmetriji koja se odnosi na metriku na razini rada i koja se bavi mjerenjem pokazatelja baziranih na društvenim mrežama, nipošto ne ukazuje na kvalitetu rada, već isključivo služi znanstvenicima da prate kulturni i društveni utjecaj vlastitoga rada.

\section{Usluga Iznajmi knjižničara}

Sveučilišna knjižnica Rijeka u svom paketu edukacijskih programa, koji su uglavnom namijenjeni grupama studenata i drugim korisničkim skupinama, ima uslugu Iznajmi knjižničara koja se odnosi na individualan rad s korisnikom. Ono što je obuhvaćeno edukacijskim paketom "Postani SVKRI znalac" moguće je održati, u skladu s potrebama korisnika, i individualno u trajanju od šezdeset minuta.

Usluga uključuje poduku korištenja Knjižnice, pretraživanje izvora na temu prema korisnikovoj potrebi, upoznavanje s programom za upravljanje bibliografskim podacima (Mendeley), te upoznavanje s bibliometrijom i webometrijom. Korisnik prema svojim potrebama bira program koji je pritom prilagođen njegovom predznanju. Edukacije u sklopu usluge Iznajmi knjižničara održavaju diplomirani knjižničari isključivo u Sveučilišnoj knjižnici Rijeka za članove Knjižnice.

Zahtjevi za individualnim edukacijama nisu toliko učestali naspram grupnih edukacija, no povratna informacija korisnika koji su zatražili tu vrstu usluge uvijek je pozitivna. Zainteresiranost i sudjelovanje korisnika u čitavom procesu razmjene informacija prisutniji su nego pri grupnom radu. Korisnici redovito odabiru ovu vrstu usluge kada je riječ o pretraživanju elektroničkih izvora za vlastita znanstvena istraživanja. Kada je riječ o programu za upravljanje bibliografskim podacima te upoznavanju s bibliometrijom i webometrijom, edukacije se uglavnom drže za specifične korisničke skupine.

\section{Sudjelovanje u izvođenju visokoškolske nastave}

Radionice Postani SVKRI znalac prepoznate su među nastavnicima Sveučilišta kao kvalitetan sadržaj informacijskog opismenjavanja, osobito kod studenata koji su pri završetku studija te pišu završne i diplomske radove. Nastavnici nas pozivaju da održavanjem radionica sudjelujemo kao podrška nastavnom procesu i njihovim kolegijima. Posljednje dvije akademske godine sudjelovali smo kao gosti predavači u okviru kolegija Seminar diplomskog rada za studente druge godine diplomskih studija psihologije i pedagogije, kojima smo održali module Pronađi u knjižnici i Organiziraj prikupljenu literaturu. Radionice prilagođavamo studiju i fakultetu na kojem održavamo radionice, čime želimo osigurati kvalitetu studijskog programa.

U akademskoj 2019./2020. godini sudjelujemo kao suradnici u izvođenju kolegija Uvod u istraživački rad u sklopu diplomskih sveučilišnih studija "Istraživanje i razvoj lijekova", "Biotehnologija u medicini" i "Medicinska kemija" Odjela za biotehnologiju Sveučilišta u Rijeci. U okviru izvedbenog plana održavamo nastavni sat predavanja Pretraživanje literature uz dodatni sat vježbe, te nastavni sat predavanja Organiziranje bibliografskih navoda s praktičnim dijelom i vježbom: Upotreba Mendeley programa za izradu bibliografije.

\section{Umjesto zaključka idemo korak dalje}

Osposobljavanje i podrška za korištenje informacijskih izvora i komunikacijskih tehnologija jedan je od važnih ciljeva suvremene visokoškolske knjižnice koja svoje poslovanje i resurse usmjerava na informacijske potrebe svojih korisnika (Petr Balog 2010). Misija Knjižnice (Sveučilišna knjižnica Rijeka 2018) usmjerena je na izgradnju informacijskih sustava studenata i nastavnika, pri čemu moramo biti usmjereni na odgojno-obrazovnu ulogu knjižnice prilagođenu novoj milenijskoj generaciji digitalnih urođenika (Arh et al. 2013). Radionice Postani SVKRI znalac postavile su dobar temelj i omogućile da u budućnosti napravimo korak dalje u provođenju programa informacijske pismenosti na Sveučilištu tako što smo u listopadu 2018. godine uveli program cjeloživotnog učenja "Informacijski alati za istraživače" koji je namijenjen istraživačkoj populaciji na Sveučilištu, ali i izvan njega. Program se sastoji od pet predmeta koji kronološki prate proces izrade, objavljivanja i vrednovanja znanstvenog rada. Program je akreditiran na Sveučilištu u Rijeci kao program cjeloživotnog učenja, a planira se ponuditi i kao kolegij/tečaj na poslijediplomskim studijima. 


\section{Literatura}

- Arh, Evgenia, Dejana Golenko, i Branka Pemper. 2013. "Digitalni urođenici u sveučilišnoj zajednici (istraživanje na Sveučilištu u Rijeci)" U Knjižnice: kamo i kako dalje? Zbornik radova. 12. dani specijalnih i visokoškolskih knjižnica, Opatija, 11.-14. svibnja 2011., 176-184. Zagreb: Hrvatsko knjižničarsko društvo.

- Cuculić, Sandra, Jana Krišković Baždarić, i Branka Pemper. 2017. "Edukacijom do prevencije plagijarizma kod studenata Sveučilišta u Rijeci (doprinos knjižničara)" Rad predstavljen na: 15. dani specijalnih $i$ visokoškolskih knjižnica, Lovran.

- IFLA. 2012. IFLA-in Etički kodeks za knjižničare $i$ druge informacijske djelatnike. https:/www.ifla.org/ files/assets/faife/codesofethics/croatiancodeofethicsfull.pdf. Datum pristupa: 7. 6. 2019.
- Petr Balog, Kornelija. 2010. Prema kulturi vrednovanja u visokoškolskim knjižnicama. Osijek: Sveučilište Josipa Jurja Strossmayera, Filozofski fakultet.

- Sveučilišna knjižnica Rijeka. 2018. Izvješće o radu $i$ poslovanju 2018. https://svkri.uniri.hr/images/dokumenti/Izvjesce_o_radu_2018.pdf. Datum pristupa: 22. 8. 2019.

- Sveučilišna knjižnica Rijeka. 2018a. Plan i program rada knjižnice 2019. https://svkri.uniri.hr/images/ T5_Plan_i_program_2019.pdf. Datum pristupa: 4. 6. $\overline{2} 019$.

\title{
BECOME SVKRI EXPERT - STUDENT INFORMATION LITERACY WORKSHOPS
}

\begin{abstract}
Because of extensive access to electronic content online, libraries have experienced a complete turn in their activities. A decline in the number of book loans and an increase in the number of physical visits and virtual services were the reason libraries have started programs of education for students in the field of information literacy. The accent has been on programs and tools related to searching, organizing and evaluating information.

In 2016 University Library Rijeka started an educational program Postani SVKRI znalac as a support for students in their studies and their research work. The first two workshops are about the library and its services, the other three are based on the knowledge and skills of searching and evaluating information.

The rapid increase of information and literature in the digital sphere requires additional education related to access to information, copyright and the increasing phenomenon of plagiarism.

Program Postani SVKRI znalac has been recognized by the professors of several classes of the University and some workshops are part of those classes in specific periods of the academic year.
\end{abstract}

Keywords: Postani SVKRI znalac, University Library Rijeka, Higher Education Library, information literacy 